\title{
Review of "Borrelia: Molecular Biology, Host interaction and Pathogenesis", by DS Samuels and JD Radolf
}

\author{
Olivier AE Sparagano
}

\section{Book Details}

Samuels DS, Radolf JD:

Borrelia: Molecular Biology, Host Interaction and Pathogenesis. Caister Academic Press; 2010, 547.

ISBN 978-1-904455-58-5

\section{Review}

Writing a book on a single genus is always very risky as it would target only a small number of scientists specialised in such narrow field. However in the case of Borrelia it would expand to other field such as vectors and vector-borne diseases, hosts-arthropod interaction, pathogen adaptation to vector and/or mammal host. This book has 18 chapters and it will cover everything you need to know about these Spirochetes from behaviour in the field to sequencing in a molecular laboratory. Each chapter seems to be written by expert in their Borrelia field and bring updated information about the state-of-art for research of simply general knowledge for this pathogen.

The most fascinating is to learn how the Spirochetes are adapting to different tick tissues, "re-programming" their genome when moving from a tick vector to a mammalian host and succeeding to by-pass the immune system of both of them to complete their life cycle. Genomic studies are showing the important of the plasmids in Borrelia cells while the molecular phylogeny will explain why we have species differences between Europe and the American continent and if it was the host or the tick which introduced the pathogen.

This book would definitely interest researchers and some teachers seeking research-led examples for their lectures on a similar topic but the small number of illustrations would require academic staff finding other visual aids to complement the data presented here. One

Correspondence: Olivier.sparagano@ncl.ac.uk

School of Agriculture, Food and Rural Development, Newcastle University, Newcastle upon Tyne, NE1 7RY, UK

(c) 2010 Sparagano; licensee BioMed Central Ltd. This is an Open Access article distributed under the terms of the Creative Commons Attribution License (http://creativecommons.org/licenses/by/2.0), which permits unrestricted use, distribution, and reproduction in any medium, provided the original work is properly cited. criticism would be that the editing steps did not prevent a few redundancies between chapters trying to reexplain what Lyme Disease or Relapsing fever are. Nevertheless this book is a fantastic source of information for scientists working on vector-borne diseases and interested in epidemiology, evolution, genomics....

I truly enjoyed reading this book and would recommend it to the readership.

\section{Competing interests}

The author serves on the Editorial Board of the Open Access Journal "Parasites and Vectors".

Received: 14 June 2010 Accepted: 17 June 2010 Published: 17 June 2010

doi:10.1186/1756-3305-3-52

Cite this article as: Sparagano: Review of "Borrelia: Molecular Biology,

Host interaction and Pathogenesis", by DS Samuels and JD Radolf.
Parasites \& Vectors 2010 3:52. and take full advantage of:

- Convenient online submission

- Thorough peer review

- No space constraints or color figure charges

- Immediate publication on acceptance

- Inclusion in PubMed, CAS, Scopus and Google Scholar

- Research which is freely available for redistribution

Submit your manuscript at

www.biomedcentral.com/submit

C Biomed Central 